OLEG SUŠA

\title{
K AKTUÁLIIM SOUVISLOSTEM INFORMATIZACE, GLOBALIZACE A INDIVIDUALIZACE
}

Máme-li pochopit transformace soudobého světa, musíme analyzovat sociální souvislosti šîrení informačnich technologii, rostoucí globalizace a individualizace života společností. S rozmachem informačních technologií souvisejí nejen sama technická média přenosu informace (telefon, televize, počítače a jejich sítě nebo tzv. integrované systémy multimédií), ale také sociokulturní a mocenské souvislosti potřeb, účelů a cílů jejich využívání, organizace a institucionalizace jejich fungování. Globalizace představuje komplex procesủ zpủsobujících rostoucí vzájemnou závislost národních společností, států, institucí a organizací, lidských společenství a jejich kulturních výtvorů. Vzájemná závislost se projevuje dvojím způsobem: fyzicky a symbolicky. Pủsobí v mnoha rovinách environmentální, ekonomické, politické, vojenské, kulturní, technické, informační aj. Informačni technologie a globalizace jsou neoddělitelně spjaty, komunikace a doprava se svými technickými prostřcdky (médii) jsou klíčovým předpokladem postupující globalizace jako časoprostorové komprese relativního zmenšování světa a globalizované sociální prostory, včetně elektronického prostoru, by reálně i virtuálně nemohly existovat bez podpory médií a informačních technologií. Oba trendy, informatizace i globalizace, značně ovlivňují společenský, politický a kulturní život, přičemž vedle reálných prostorủ moci pủsobí také virtuální prostor vztahování, srovnávání a vzájemného konfrontování rủzných sociálních aktérů. Média sdělování zprostředkovávají $v$ tomto virtuálním prostoru symbolické sociální vztahy vzájemné zkušenosti a lidé usuzují často podle mediálně produkovaných obrazủ světa. Reálné změny moci v sociálních vztazích jsou překrývány různými formami reflexe procesu individualizace. Individualizace může mít význam egocentrizace či personalizace, může být hédonická, anebo vynucená situacemi a poměry, za jistých okolností se však může jevit jako zbezmocnění jednajících individuí. Je podoba soudobého procesu individualizace pokračováním především odtradičnění, nebo je pokračováním realizace projektu moderní či postmoderní emancipace? Jaká je souvislost mezi makrosociálním pohybem globalizace společností a současným kontextem individualizace? Zdá se, že charakter současné globalizace se promítá do podmínek a zaměření individualizace společnosti. 


\section{INFORMAČNI SPOLECNOST, SOCIÁNÍ PROSTORY A GLOBALIZACE}

Pohled na složité souvislosti mezi makrosociálním procesem globalizace jako komplexní transformací a procesem individualizace sociálního života může začínat analýzou aktuálních i minulých reflexí změn spojených $\mathrm{s}$ informatizací a globalizací $\mathrm{v}$ podobě teorií informačni revoluce a informačni společnosti, teorii globálního věku či globalizace sociálního života. Vždyt ještě na prahu 80 . let 20 . století převládaly optimistické naděje, které předpokládaly, že $\mathrm{v}$ budoucnu informační postindustriální či počítačová revoluce povede $\mathrm{k}$ řešení, anebo zmírnění ekologických problémů naší planety $\mathrm{v}$ dủsledku snížení energetické náročnosti restrukturovaného prủmyslu, „lehké“ či jemné vysoké technologie umožní nejen snížit spotřebu hmotných, ale i lidských neobnovitelných zdrojủ $\mathrm{v}$ důsledku tzv. intelektualizace produkce, což povede $\mathrm{k}$ humanizaci lidské práce a společenského i kulturního rozvoje $v$ technologicky nejvyspělejších společnostech, $\mathrm{k}$ rủstu volného času, $\mathrm{k}$ tvůrčímu uvolnění lidských potencialit nadání a vloh, $\mathrm{k}$ emancipaci a sebeuskutečnění lidského individua [Toffler, Drucker].

Nové technologie měly podle některých sociologických analýz a previzí právě díky tzv. intelektualizaci produkce napomoci novému zhodnocení člověka a rozvoje lidského duchovního tvůrčího potenciálu seberealizace. Tento proces měl posílít novou revoluci lidských hodnot a umožnit také zásadní transformace sociálních institucí a struktur [Fergussonová, Theobald] včetně všeobecné decentralizace moci a odbyrokratizování společnosti, demokratizace účasti na rozhodování, etiky odpovědnosti a stylu života „dobrovolné skromnosti“ [Elgin] orientovaného nikoli k cílủm zisku a hromadění moci a věcí, ale na vlastní kreativní seberealizaci lidských individuí.

Dnes se ukazuje, že technické změny přinášejí nejen technické výhody, operační rychlost a ekonomickou efektivnost, ale také dvojznačné sociální a kulturní (připadně nezamýšlené) dủsledky $\mathrm{v}$ lokálním i globálním kontextu. Tyto změny je navíc nutno reflektovat $v$ sociálnim kontextu mocenských zájmů politických a hlavně ekonomických, jež poznamenávají cíle a předpoklady jejich rozvoje, aplikace i šíření. $\mathrm{V}$ tomto smyslu nelze technologie obecně a informační technologie (dále jen IT) zvláště považovat za sociálně neutrální, čistě technické nástroje či „nepolitická“" média, nebo naopak je chápat jako všemocné, autonomně působící zázračné proutky. Jak např́ílad ukázal A. Smith, byly ideje vystupující jako imperativy doby (vůdčí ideologie) koncem 20. století vystřídány koncepcí informační revoluce jakožto nositele transformačních a paradigmatických idejí staletí [Smith 1996: 33].

Závažnou je $\mathrm{v}$ této souvislosti otázka, zda je možno usuzovat, že díky změnám $\mathrm{v}$ důsledku informatizace a globalizace se mění i sociální povaha člověka, kterou je možno spolu $\mathbf{s}$. Habermasem pojímat ve dvou dimenzích práce a jazykové komunikace [Habermas 1981, I]. Nemění se s tím rovněž kvalita sociální evoluce člověka ve vzájemné spojitosti práce a komunikace, instrumentality a smyslu lidského života? Zdá se, že nová média elektronické komunikace zasahují a budou zasahovat nejen do povahy lidské komunikace, ale také do povahy práce a organizace. Práce se stále více stává komunikací ve smyslu zpracovávání informací a dat a „vědění vyrábějícího věděni". Sociální cíle zaměření a využití IT ovlivnily samožrejmě také nové organizační formy „flexibilizace“ a „sítováni““ (networking). 
Ekonomická globalizace a globální komunikace využivající nových médií IT vytvářejí dnes nové a širši nadnárodni prostory, ve kterých se mění mocenský poměr kapitálu a práce. Zdá se, že kapitál se stává vzácnějším a „dražšim“ nežli práce. Práce jakožto zboží - ve smyslu pracovní síly na trhu práce - začíná být $\mathrm{v}$ rámci technologické strukturální změny a v globalizovaných prostorech vzájemné závislosti nadbytečnou (případně zbytečnou) a stále „levnější“. Dủsledky takového vztahu reflektují například soudobé koncepty tzv. kapitalismu bez práce [Beck 1996, 1999, 2000] či „globálního věku“, ve kterém bohatství přeživá, aniž potřebuje „své chudé“ [Bauman 2000].

V těchto kontextech využití nových technologii pak vznikají nové politické otazniky, mj. zda bude společnost budoucnosti společností bez práce, nebo zda nové technologie slouži především dalši instrumentalizaci lidí a větši kontrole i moci nad lidmi - třebas v hávu príijemné konzumni nesvobody tzv. personalizace [Marcuse, Lipovetski], anebo zda slouží spiše možnostem daľsi demokratizace života a podpoře rozvoje lidského tvưrčího potenciálu. Čím nahradí moderní civilizace případný reálně sociálně strukturovaný zánik kulturní hodnoty lidské práce, jak politicky řešit širší dủsledky rostoucí globálni nezaměstnanosti?

\section{PROSTORY GLOBALIZACE, SITĚ̈, AKTÉR̆I A SOCIÁLNI ZÁJMY}

Stále aktuálnějším problémem se stává charakter nadnárodních prostorủ, jež konkuruji tradičním mezinárodním vztahủm. Nadstátní, nadnárodní prostory jsou spojeny $s$ vystupňovanou intenzitou informačni technologické komunikace a s globalizovanou infrastrukturou počitačových sití, s globálním televizním vysíláním, s internetem a elektronickou poštou. Od šedesátých let došlo $\mathrm{k}$ tryskovému růstu globální letecké či kontejnerové dopravy. S globalizovanými formami produkce a organizace se globalizují rủzné trhy. Finanční operace, obchody a transakce probíhají stále rychleji díky elektronické komunikaci v nadnárodních prostorech.

Podniky a organizace jsou nestálejší, přechodné, méně formalizované. $\mathrm{V}$ tomto kontextu neudivuje velmi rozšǐřený názor, že soudobá vlna či etapa globalizace je nesena historicky novými technikami komunikace, informační či mediální revolucí. Příznačným rysem nových prostorủ globalizace je jejich rychlost, nestálost a přechodnost, popřípadě také neprůhlednost proměnlivých sítí vztahủ, jež jsou rychle navazovány a zase rozvazovány. Jejich dủsledky navíc posilují turbulentnost reorganizací mnoha ekonomických i státních institucí, přispívají $\mathrm{k}$ destabilizaci situací a kontextů jednání aktérů a vyžadují pružné reakce. S touto flexibilizací se ovšem také stupňuje klima nejistot, rizik a vágni dủvěry $\mathrm{v}$ institucionální řešení a fungování významných sociálních vztahủ.

$\mathrm{Na}$ mcluhanovské motivy tzv. globální vesnice ve smyslu relativního zmenšování světa stlačenim prostorových zeměpisných distancí a zkrácením časových úsekủ navázali v osmdesátých a devadesátých letech napřiklad Harvey, Castells nebo Giddens svými analýzami časoprostorového stlačení, utváření tzv. sítové společnosti a vztahů na globální vzdálenosti. Oproti starším futurologickým koncepcím tzv. informační společnosti Tofflera, Masudy - jež se koncentrovaly hlavně na aspekt techniky jako víceméně nezávislého faktoru nezadržitelně pủsobícího na společenský život - formulují zmíněné koncepce globalizace informační technologickou komunikaci jakožto 
obecnou kulturni sílu, globální proces a sociálni produkt, na který působí sociální zájmy a mocenské cíle $i$ vztahy. Právě zájmy a mocenské vztahy utvářely v poslední třetině minulého století charakter uplatnění nových informačních technologií.

Informační technologická globalizace se stala činitelem i předpokladem transformace celé řady oblastí sociálního života. Sám McLuhan mluvil o třetí technické revoluci v kultuře. Kulturní revolucí je podle něj nikoli změna kulturních obsahủ, nýbrž především změna médií přenosu a šíření kultury, jež zpủsobuje rozšǐření smyslového vnímání (média komunikace a dopravy zvláště). Globální sítě komunikace jsou pro něho analogií lidské centrální nervové soustavy, imploze elektrického věku ve smyslu strukturálního efektu elektronické komunikace a zrychlující se dopravy umožňuje podle něho jednak propojení lidské zkušenosti, jednak také zakoušení světa jakožto celku. Svět jako „globální vesnice“ bude výrazem nové vzájemné závislosti lidí, která připomíná kmenovou pospolitost. Elektrický věk bude podle McLuhanova optimistického scénáře svržením nadvlády času a prostoru a obnoví dialog v globálním měřítku [McLuhan 1991].

J. Rosenau ve své analýze nadnárodních ,postmezinárodních vztahư" rovněž považuje vlivy postindustriálních mikroelektronických technologií za př́činu podstatné redukce globálních distancí a rychlého pohybu lidí, idejí a zdrojů po naší planetě. Globalizace vytváří nové, tzv. planetárni problémy, jež nemohou řešit státy na své národní základně, vznikají nové mocné subkolektivity uvnitř národních společností, rủst úrovně odbornosti, vzdělanosti a reflexivních schopností obyvatel snižuje jejich podřízenost kontrolní moci národního státu. Technický rozvoj v oblasti mikroelektroniky způsobil nestálost a turbulentnost ve světě i uvnitř národních společností [Rosenau 1990]. Casoprostorová komprese [Harvey 1989] světa proběhla nejrychleji v hospodářské oblasti v rámci tzv. ekonomické globalizace.

$\mathrm{V}$ této souvislosti I. Ramonet z francouzského časopisu Svět diplomacie mluví o novém informačním globálním kapitalismu, reprezentovaném zejména telekomunikačními podniky. Globální komunikace informací je technicky založena na digitalizaci umožňující sítování komunikačních služeb a fúzi telefonu, televize a počítače $\mathrm{v}$ podobě multimédií a internetu. Telekomunikační, telefonní a televizní obři jsou v nemilosrdné válce o teritoria nadnárodních trhů, kde se na ně napojují sítě dalších výrobců a dodavatelủ (infrastruktur energetiky, dopravy, vodohospodárství atd.). $\mathrm{V}$ podmínkách trhu se stálou nepředvídatelnou technickou inovací a akcelerací je strategickým cílem nemilosrdné zničení konkurentů a ukořistění nejnovějších úspěšně etablovaných know-how. Využití všech infrastruktur v globalizovaném nadnárodním prostoru potřebuje deregulaci a volný pohyb informace a kapitálu. Ramonet uvádí celou raadu gigantických firem v prủmyslu médií a informačních technologii: AT\&T, spojení MCI a British Telecom, Sprint, Cable a. Wireless, Bell A'tlantic, Nynex, US-West, TCI, NTT, Disney, Time Warner, News Corp., IBM, Microsoft, Netscape, Intel a dalši [Ramonet 1998: 170-174].

Soudobá globalizace je snad nejspecifičtější svými nadnárodními vztahy a interakcemi, jež se rozvijejí také ve virtuálním elektronickém prostoru (electronic space). Podle Saskie Sassenové narủstá v životě společností a v globalizovaných vztazích moci politický význam elektronického prostoru. Jde především o to, zda je tento prostor komunikace prostorem veřejným, či zda jde spíše o prostor soukromý. Tento problém se stále více jeví jako souboj veřejného se soukromým, protože $v$ devadesátých letech 
je již patrné, že i elektronický prostor komunikace začal být rovněž „kolonizován systémem" - $\mathrm{s}$ tím, jak narůstá využití e-prostoru jako arény akumulace kapitálu a operací globálních aktérů.

S. Sassenová rozebrala tuto politickou problematiku jako otázku disperze a koncentrace moci v elektronickém prostoru na případě internetu. Ještě počátkem devadesátých let se soudilo, že internet neumožní autoritářské vztahy a monopolní kontrolu. Tato sít zpočátku fungovala $v$ souladu s kulturou počítačových hackerủ a nadšencủ pro virtuální komunikaci a sdružování lidí, kteři chtěli praktikovat „životní svět" otevřené a mocensky neovlivňované komunikace, s př́istupem do sítě bez poplatku. Stejně tak jako byla většina jiných elektronických síti od začátku soukromá a komerční, narůstá i v prostoru internetu od poloviny devadesátých let privatizace a komercializace [Sassen 1999: 49].

Takto i virtuální prostor globálních vztahủ v elektronických sítích podle Sassenové „reprodukuje hierarchii a koncentraci moci“, nap̌̌íklad globální finanční trhy, jež operují výhradně na soukromých sítích, distancují „technologické chudé a bohaté“ (jak firmy tak spotřebitele), segmentují a rozdělují. Kyberprostor odráží nerovnosti v přístupu, možnostech a ve svobodě pohybu. $V$ globálních sítích komunikace narủstá protiklad ,mocných ekonomických aktérů a občanských společností - což vyžaduje politický př́stup“" [tamtéž: 51].

Podle Sassenové je dủležitý právě širši sociální globální kontext. Komercializace komunikačních sítí jakožto virtuálních prostorů globality je spojena s postupující koncentrací moci, zdrojủ, infrastruktur v zeměpisném prostoru globálních velkoměst jako strategických center moci a rozhodování. Globalizace a digitalizace posilily trend vytváření globálních aliancí mezi firmami, což bylo již dřive nazváno termínem „nová diplomacie“" [srov. S. Strangeová 1994], dále trend masivní koncentrace kapitálu a moci velkých korporací. Sassenová podobně jako Ramonet a dalši analytici soudobé globalizace upozorňuje, že „globální elektronický prostor se stal místem operací globálního kapitálu a vytváření nových mocenských struktur“ [Sasssen 1999: 53]. A právě v takovémto kontextu lze posuzovat ostré snahy o deregulaci a privatizaci, které umožnily telekomunikačnímu průmyslu operovat vskutku globálně a pronikat do dalších sektorů hospodářského života.

Sociální souvislosti IT je třeba posuzovat $\mathrm{z}$ hlediska aktuálních kontextů globalizace i individualizace, abychom viděli, že např́klad možnosti koncentrace či disperze moci, centralizace nebo autonomní participace jako sociálních důsledků nových technických prostředků nejsou zásadní volbou jednotlivého uživatele. Připomeňme si stručně fakt, že nové elektronické technologie již samotným svým vznikem byly úzce spojeny s mocenskými zájmy: počítač, systémová analýza a komunikačni systémy byly jako produkty vojenského výzkumu a vývoje postupně nasazovány ve státní správě a ve vědeckém výzkumu a konečně aplikovány $v$ průmyslové sféře výroby, služeb i masové kultury, zábavy i veřejné komunikace $v$ širším prostoru občanské společnosti. Od počátku koncipování nových IT šlo jak o veřejné, tak o soukromé zájmy v kontextu reálných podmínek sociálního života. Radikální soud by mohl znít takto: jak ve vojenství, tak v prủmyslu šlo od počátku především o mocenské zájmy využívání techniky. K tomuto závěru došel ve své analýze napřiklad B. Smart s tím, že o rozvoj IT se nezasloužily zájmy vědců a nadšených zlepšovatelů o ušlechtilé cíle zlepšení lid- 
ského údělu pomocí baconovských „nových organon“, ale že šlo především o cíle manipulací vojenského velení a organizací průmyslových podniků. Nasazení nových technických prostředkủ $\mathrm{k}$ uskutečňování starých sociálních cílủ určuje také soudobou sociálně-ekonomickou konfiguraci [Smart 1990: 44-46].

Seriózní úvahy o kontextualizaci sociálních dopadů technologických přeměn práce a komunikace musí tedy odmítnout technologický optimismus některých teorii „,informační společnosti“ $i$ efektní pesimismus soudủ typu: informační společnost a její globalizace jsou produktem fatální evoluce technické civilizace. Většina analýz svědčí spíše o tom, že tváŕ informačních technologií v kontextu soudobé sociální konfigurace $\mathrm{v}$ kontextu postupující globalizace je komplexním produktem zájmủ a rozhodnutí v klíčových institucionálních strukturách (podniku i státu).

M. Castells ve své analýze transformací v tzv. informačním věku charakterizoval soudobou globalizaci jako nové globální přestrukturování moci $\mathbf{v}$ podobě duality sociálních prostorů [Castells 1996, 2004]. Duální model sociálních prostorů je kontrastem prostoru tokủ (space of flows) a prostoru mist (space of places). Hlavním prostorem byl dosud zeměpisný rámec národních států. Dnešní státy udržují monopoly moci vůči svým občanủm a kontrolují prostředky ozbrojeného násilí, nicméně podniky a organizace ekonomického života i vědecko-technické inovace se již značně vymanily $\mathrm{z}$ tohoto rámce bývalého monopolu moci legitimizovaného pojmem státní suverenita. Postupující globalizace ekonomického prostoru a ekonomické moci vytvořila prostorovou dualizaci. Podle Castellse jsou klíčová strategická rozhodnutí informatizovaného kapitalismu soustředěna v prostoru tokủ (kapitálu, informací). Státy, sociální instituce a jednotlivci se reprodukují v prostoru míst, kdežto kapitál se reprodukuje $\mathrm{v}$ sítích prostoru toků. Dualita prostorů je také kontrastem mezi ekonomickou a politickou mocí: zatímco politická moc v národním státě podléhá možnosti relativně demokratické kontroly zdola, síly globálního kapitálu a sítových korporací se politické kontrole vyhýbají, mohou prosazovat svoje hospodářské politické cíle a $\mathrm{k}$ tomu využívat nadnárodní globální organizace k nátlaku na jednotlivé státy. Globalizované korporace nepřímo přebírají od států také kontrolu trhů práce, přestože tyto trhy zůstávají stále omezeny v prostorech míst. Korporace trhy práce navštěvují a opouštějí, státy a jejich vlády spolu soutěží o přizeň investorů, tzn. finančních, obchodních i prủmyslových podnikủ. Dualita paralelních světů je dualitou národně-státních společností a globální nadnárodní společnosti sítí (network society). Globálně sítující podniky rychle mění svou strukturu, tvary organizace i svou sociální strukturu: zmenšují stálé osazenstvo, rychle navazují a ruší sítě spolupráce a koalice, sítě dodavatelských a odběratelských vztahů, rozšiřují praktiky outsourcingu atd. Dopady interakce mezi sítovou společností a prostory míst vytvářejí rostoucí nestálost a nejistotu života jednotlivců závislých na trzích práce.

\section{SOCIÁLNI A KULTURNI DÚSLEDKY GLOBALIZACE}

Dopady na práci a kulturní život $\mathrm{v}$ rámci rostoucího vlivu nadnárodních a globalizovaných prostorů na strukturální destabilizaci lokálních (reálných, národních) společností jsou dalším př́ikladem komplexních transformací. Tak např́klad ekonomická 
globalizace mající dopady na situace trhu práce je spojena s novými pružnými formami organizace podniku. Nové techniky umožňuji nejen pružnost ve smyslu proměnlivosti a někdy též tvořivosti práce, umožňují hlavně snižovat množství pracovních sil, zlevňovat duševní práci a zhodnocovat („zdražovat“) kapitál. Za heslem flexibility a flexibilizace vidíme fakt, že dochází $\mathrm{k}$ zásadní transformaci vztahủ mezi zaměstnavateli a zaměstnanci a $k$ posunu moci na stranu managementu. Pružné systémy organizace umožnily podř́ídit jednotlivce hegemonii managementu a (nadnárodnč) mobilního kapitálu [Harvey 1989: 167]. Cílem využití nových technik je především využit vědění a informace ke kontrole a udržování moci. Decentralizace organizací práce v nadnárodních globalizovaných prostorech je spjata s centralizací strategického řízení a rozhodování.

Transformace pracovních vztahů maji jako svůj hlavní lokální i globální důsledek zvyšováni nezaměstnanosti, polozaměstnanosti či neúplné, dílčí zaměstnanosti (tzv. podzaměstnanosti). Globalizace trhủ práce je ovlivněna konkurencí, rychlostí inovace a má sociální dopad jak v zemích rozvojových, tak i v rozvinutých. Strukturální změny pracovního trhu působí na dualizace a segmentace pracovních sil. Přitom se prohlubují např. mzdové propasti a narůstá nezaměstnanost. $V$ rozvojových zemích spolupůsobí technologická a sociální nezaměstnanost i větší tempo populačního rủstu. Ve vyspělých společnostech roste nezaměstnanost i dilči zaměstnanost nejen u manuálních a méně kvalifikovaných, ale rovněž stále více u duševních a kvalifikovaných lidí. V globálním měřitku narůstá tzv. globální třída chudých (global underclass) [srov. Miller 1995]. Podle výzkumů Mezinárodní organizace práce (ILO) nezaměstnost ve světě nadále roste a možnosti zaměstnanosti jsou podminěny také globálně, závislostí rozvojových zemí na proexportním rozvoji a situaci na trzích bohatých zemí Západu [ILO 2003].

Dualizace a segmentace pracovních sil vytváři sociální polarizace - na jedné straně stále menšího počtu stálých (tzv. jádrových) zaměstnancủ, na straně druhé stále většího počtu marginálnich (tzv. perifernich) pracovníkủ. To se odráži ve zpružnění pracovních smluv a v tendenci snižovat sociální odpovědnost zaměstnavatele [Harvey 1989; Castells 1996; Beck 1996; Sassen 2000]. Prohloubení tvrdé kapitalistické logiky od osmdesátých let podpořila politika a ideologie deregulace a privatizace. Do kontextu kapitalistické globalizace poslední třetiny minulého století zapadá také stálý rủst technické inovace a konkurence. $V$ organizaci podnikủ na principech najímání dočasných služeb podniků, sítí výrobců i pracovníků dochází $\mathrm{k}$ individualizaci a sociální izolaci nájemné práce. Segmentace práce je stratifikována v podstatě ve třech úrovních kategorii pracovníkủ: globálně mobilních, rekvalifikovatelných, nezaměstnaných či marginalizovaných lidí.

Globalizace organizace práce i trhủ práce sociálně dezintegruje, oslabuje v reálných společnostech sociální solidaritu a koresponduje s mocenskými posuny v oslabování vlivu odborů ve stávající institucionalizaci průmyslových vztahů zejména ve vyspělých demokratických společnostech. Podle Harveye a Castellse vede segmentace a dualizace práce také k dualizacím společností [Harvey 1989; Castells 1996] . Lidská práce se vymanila $\mathrm{z}$ kolektivních sociálních a sociokulturních i politických rámcủ a je stále více individualizována, závisí na individuálním vyjednávání se zaměstnavateli 
a na rychle se měnícím trhu práce. Zdá se, že informační společnost jako globalizovaná společnost sítí a sítování je rozdělována na „vítěze“ a ,poražené“ v nekončícím procesu nerovného individualizovaného vyjednávání.

Rostoucí nezaměstnanost vytvárí širší společenský a politický problém sociální anomie a marginalizace či vyloučení množící se skupiny lidí, kteří zakoušejí, zakusili nebo zakusí pocity méněcennosti, zbytečnosti, neužitečnosti a sociální nepotřebnosti [Sennett 1999: 17]. Takto napríklad narůstá počet mladých lidí s nižšim i nejvyšším vzděláním, kteři nemají stabilní jistotu zaměstnání $\mathrm{v}$ bohatých a vyspělých moderních společnostech vyznávajících ideály politiky meritokracie. Paradoxní odpovědí na technickou a organizační racionalizaci práce flexibilizací a zmenšováním zaměstnanosti i v oblasti duševní tvůrčí práce snad má být pštrosí politika flexibilizace a deregulace vyjadřovaná „odpovědi“": méně pracovníkủ přinese větší bohatství menší skupině lidí a ti ostatní, přebyteční, snad někam zmizí?

Otazníky nad důsledky informatizace a globalizace $v$ její stávající socioekonomické konfiguraci přinesly také následující otázku: Jestliže se zdá, že technika v reálném, stále více globálně propojovaném mocenském kontextu měni práci i sociální stratifikaci, mizí také práce jako kulturní ideál, centrum smyslu života ve společnosti práce? Je to konec společnosti práce? [Offe 2000: 196.] Znamená to, že v existenci lidí nahradi seberealizaci $v$ práci seberealizace ve volném čase a že práci nahradí zábava? Volný čas i zábava jsou zbožím stejně jako práce anebo informace, za zboží se platí, jaké zboží bude moci konzumovat napríklad dlouhodobě nezaměstnaný?

V souvislosti s kulturními významy a smyslem lidské existence i s volným časem se aktualizují také další kontexty informatizace v oblasti „masového kulturního průmyslu“ [Adorno] zábavy v rámci soudobé „info-kultury“ (tzv. info-cult). $\mathrm{Z}$ hlediska technologické změny a inovačních procesů $\mathrm{v}$ oblasti médií komunikace jsou aktuální trendy přesunu od televize $\mathrm{k}$ multimédiím. Hlavní roli zde hraje počítač a elektronický prostor komunikace, tvořící nové médium - tzv. CMC (computer mediated communication). Interaktivnost se posiluje propojením televize, telefonu a počítače $v$ sítích. V multimédiích se integrují zvuky, texty, obrazy do jednoho systému. Některé technicistní utopie věŕi v růst tvưrči svobody personalizace rozhodování jednotlivce jako spotřebitele komunikačních služeb, uživatele média, ale také konzumenta určitých kulturních obsahủ. Věŕi v možnosti nových interaktivních technik ve směru překonání jednostranností a pasivního receptivismu klasických médií - především televize.

Zdá se, že televize sama přinesla určité klišé kulturní komunikace, $v$ němž stále více dominuje zábava a kultivačni funkce je sporná. Televize především rozvinula systém masového kulturního průmyslu zábavy ve 20 . století. Tento zábavní průmysl vyrábí a nabízí ke spotřebě obrazy, symboly a simulakra, jež představují simulační modely vytvářející hyperrealitu. Podle J. Baudrillarda jsou simulakra výsledkem manipulace skutečnosti pomocí forem médií sdělování informace [Baudrillard 1983]. Obsah zpráv je sekundární (obdobný názor měl dřive i McLuhan), snahy o demokratizaci a kontrolu obsahu procesủ komunikace informací nemají podle Baudrillarda výraznější výsledky proto, že nemění formu, která spojuje média se systémy moci, média ruší rozdíl mezi simulací a realitou, je stále nesnadnější rozlišit falešné a pravdivé, realitu a fikci. Skutečnost je představována symboly a znaky. Symboly a znaky tak vlastně 
zastupují realitu a divák je vtahován do simulované, virtuální, uměle vytvářené, či konstruované skutečnosti. Sféra simulaker a kódủ zakládá globální proces tvorby kapitálu. Média nepodávají informaci, slouží spíše ke kontrole a testování. Technologicky vzniká jakýsi hybrid, jenž ovšem více či méně pủsobi na kulturní život, na vědomí lidí. Nejde však jen o to, že médium je hlavní a v určitém smyslu supluje obsah [McLuhan], jde také o obsah komunikací, v němž stále převládá komerční zábavnost nad poučením a vaděláváním [Castells 1996: 337].

Dnešní multimediální prủmysl, jehož moc zároveň globalizuje a je globalizována, vytváří „sítovou kulturu reálné virtuality“, v níž je skutečnost lidské existence přetvářena do soustavy virtuálních obrazů fiktivního světa. Prostředky komunikace se tak stávají samotnou zkušeností.

Rozporuplnou sociální i politickou otázkou se dnes stává především míra dostupnosti využití interaktivních médií - tzn. otázka otevřenosti sítové elektronické komunikace - pro širší vrstvy lidí. S tím souvisí otázky nové stratifikace - a tím i sociální nerovnosti - informačních vítězů a poražených. Ještě v polovině 90 . let se domnívali např. Castells nebo $Z$. Bauman, že kupř. internet využívá jen malý segment společnosti (západní), jiní mluvili globálně asi jen o deseti procentech obyvatel světa [Offe 2000]. Bauman uzavírá, že internet je „spíše než brána“ jen „úzkou štěrbinou v tlusté zdi“ [Bauman 2000: 87]. I. Ramonet odhadoval, že uživatelů internetu bude kolem r. 2001 již asi 600 milionů až jedna miliarda a celosvětová sít bude mít asi sto tisíc komerčních webových stránek, to znamená, že by již šlo o jednu šestinu lidstva.

Ramonet i Castells konstatovali fúzi televize, telefonu a počítače na bázi digitální technologie a s tím spojený rozmach nového „informačně technického komplexu“ (obdoba vojensko-průmyslového komplexu). Převažuje zde orientace na masovou zábavu (entertainment industry) a tento komplex mocensky usiluje hlavně o kontrolu obsahu kulturní komunikace, $\mathrm{v}$ níž jsou omezovány vzdělávací a intelektuální hodnoty. Dominantní strategií je komerční prodej levné masové zábavy ve stereotypech [Castells 1996; Lash 1999]. Ukazuje se však, že tato strategie naráži paradoxně na limity $\mathrm{v}$ kontextu individualizované personalizace stylů života, $\mathrm{v}$ nichž narůstá proporce jednak pracovního času $v$ situaci částečné zaměstnanosti a nutnosti skládaných př́jmů $z$ více výdělků, jednak na narůstajíci pluralizaci aktivit ve volném čase.

Castells hovoří o kulturni segmentaci společnosti podle způsobu využití médií, jejichž uživatele dělí na „interagujíci““ - ty, kteří samostatně volí a určují výběry a „,interagované“ - ty, kteři jsou „spíše pasivně řízeni předvolbami nabídky“" [Castells 1996: 371]. Také Bauman soudí, že média spíše lidi rozděluji, McLuhanův sen o světě jako globální vesnici se nesplnil a lidé i společnosti ve světě jsou separováni. Televize podle jeho názoru spíše lidi zbavuje schopnosti spolu opravdově komunikovat v globální vesnici bydlí cizinci [Bauman 1995]. Jde o novou polaritu globálnĕ mobilních svobodných na jedné straně a na straně druhé lokálních, méně svobodných, kteří jsou připoutání $\mathrm{k}$ místu a $\mathrm{k}$ televizoru, $\mathrm{v}$ němž mohou denně sledovat ty globální svobodné [Bauman 2000]. Separované lidské existence a nedobrovolná i dobrovolná exkluze v globalizovaných prostorech vytváři spíše „kulturu lhostejnosti“ v „posthumánním věku věcí“ [Lash 1999: 11]. Robins a Webster dokonce tvrdí, že média informační společnosti nepřinesla svobodné proudění informací pro zlepšení kvality komu- 
nikace, lidského porozumění a sociální harmonie. Média nejsou nevinným a sociálně neutrálním nástrojem. Hlavním cílem tu není komunikovat, ale prodávat a stimulovat další konzum, centralizovat moc, kontrolu a dozor [Smart 1990].

Média interaktivní komunikace, jako např́íklad internet, jsou potenciálně využitelná pro veřejné cíle občanské společnosti a pro demokratizaci založenou na účasti občanů v rozhodování, pro různá hnutí zdola, nevládní organizace, svépomocné sítě občanů, alternativní společenství životních stylů, pro sociální i politickou solidaritu atd. Vyvstává otázka, zda a jak udržovat či rozvíjet tento potenciál $\mathrm{k}$ využití pro demokratizaci v globálních vzájemných závislostech a v politice globalizace. Prostory globálních informačních sítí jsou také využivány pro nedemokratické partikulární cíle mezinárodního či nadnárodního terorismu, pirátství a organizovaného zločinu, internetové obchody obsahují často kriminální podniky dětské pornografie, obchodu $s$ lidmi atd.

Mủže být sítová informační kultura hyperreálného a globálního elektronického prostoru platformou pro náhradní lidská společenství v životním světě rostoucí individualizace a personalizace, může se stát nástrojem $\mathrm{k}$ prohloubení demokratičnosti společenských institucí, například k posílení př́mé demokracie voličủ? Na tyto možnosti bude mít jistě vliv celá řada sociálních podmínek a kontextů ovlivňujících v zásadně výraznější miŕe možnosti přístupu ve využívání, účasti na demokratické kontrole a spoluurčování obsahových stránek informační kultury v sítovém elektronickém prostoru jakožto prostoru veřejném. $\mathrm{K}$ tomu, aby se například internet mohl stát technickým prostředkem ke zvyšování „kolektivní inteligence lidstva“ [Lévy 2000] a „potenciálně nejdůležitějším nástrojem kritické veřejnosti“ [Buchstein 2000: 977], bude nezbytné vytvořit celý komplex širších předpokladů i sociálních, nejen technických. H. Buchstein přirovnal internet $k$ Habermasovu ideálu diskuse neomezené mocí s potenciálními charakteristikami univerzálnosti, rychlosti organizování občanských politických akcí, nezávislosti na moci politikủ a státních institucí, snadnosti přístupu. Zároveň konstatoval, že „mezi zaslíbenou zemí demokratické infrastruktury a momentální sítovou realitou zeje hluboká propast. Šance tuto propast v budoucnu překonat nejsou př́iliš slibné“ [Buchstein 2000: 975].

Důvodem jsou námi již zmíněné trendy segmentací, individualizující izolovanosti jednotlivcủ, které znesnadňují kolektivní jednání a sdílení společné každodenní zkušenosti. Rovněž soudobá počítačová kultura kyberprostoru navozuje často personalizující postoje exkluze individua jako aspekt jeho „svobodné volby“ závislosti na technice médií a na konzumu. Libertinské pojetí svobody legitimizuje současné vítěze globální modernizace s cílem zajistit maximální individualismus a soukromý únik (od společnosti a politiky), současně s netečností k pštrosím politikám deregulací, flexibilizací zaměstnanosti a organizované neodpovědnosti tváří $\mathrm{v}$ tvár̆ globálním problémům životního prostředí.

Globálni a lokálni kontexty nelze od sebe oddělovat z hlediska sociálních dopadů: $v$ oblasti lidské práce a organizace i v oblasti spotřeby jsou prostory komunikace ovlivňovány mocenskými zájmy a vztahy, často se prohlubuje segmentace, dualizace a atomizace či rozdrobenost, nastávaji eroze kolektivních solidarit i fungování stávajících moderních sociálních institucí - a tím se samozřejmě zrychluje eroze jistot a důvěry 
v sociálním životě v rámci fenoménu rizikové společnosti. Dochází ke zrychlování změn a ke komplikacím při adaptaci, v oblasti trhu pokračuje dravá soutěž, kterou lze stále obtížněji zmírňovat politikou účinnou v teritoriální sociální realitě ( $v$ rámci společností národních států). Principiální potenciál globální informační společnosti k univerzálnimu propojování lidské komunikace v podobě kosmopolitiních solidarit, popřípadě $k$ větší demokratizaci fungování sociálních institucí a $k$ větší miře globální spravedlnosti při využití nových technologií, nevede zatím k tak velkému dorozumění, jakého by bylo $\mathrm{k}$ nové demokratické politice komplexního řešení problémů soudobých globálních transformací zapotřebí. Mocenské cíle institucí, jako jsou byznys (podniky) nebo stát, formuji či deformuji často také rozvoj informačních médii komunikace a za těmito cíli vystupuje především komerční či partikulární, soukromý zájem - individuí, mocenských elit či institucionálních oligarchii. Sama média jsou komercializována a chovají se spíše než jako platforma veřejného diskurzu a svobodné rovné informační výměny jako podniky sledující své komerční cíle. Obrazy a simulakra, která média globálně přenášejí ve snaze manipulovat především rủst spotřeby, mohou přispívat $\mathrm{k}$ rủstu napětí mezi menšinou globálně úspěšných a většinou ohrožovanou sociálnimi a ekologickými riziky, popřípadě sociálním nebo kulturním (a politickým) vylučováním. Informatizace $\mathbf{v}$ tzv. globální vesnici tak mủže posilovat pocity globální nespravedlnosti.

Vyvstává otázka, zda vytvoření nových technických prostorů hyperreality, jež pomocí elektronické komunikace spojují lokalitu a globalitu a přitom paradoxně znovu svět rozdělují a segmentují, resp. regionalizuji v rámci hybridního umělého prostoru tzv. třetí civilizační prírody [Luke 1995, 1999], nevede $\mathrm{k}$ obnovené potřebě lidí oceňovat misto, v němž každodenně žijí. Také obnovení hodnot sociální identity a příslušnosti je často reakcí [Castells 2004] na globalizující změny ekonomického a technologického systému s dopady kolonizace životních světủ každodenní lidské existence v podobě nedobrovolného vylučování či riskantního osvobozování od potřeby (a nutnosti) práce.

\section{INDIVIDUALIZACE JAKO PERSONALIZACE: G. LIPOVETSKY}

Na počátku osmdesátých let dvacátého století se francouzské postmoderní kultuře jevil individualizační proces jako jisté pokračování moderního projektu emancipace. Jako takový proces byla $\mathrm{v}$ sociologii individualizace sledována především $\mathrm{v}$ širších kulturních kontextech a podobách rozvinutých $\mathrm{v}$ západních společnostech. Takto napřiklad G. Lipovetsky spojuje personalizaci s postmoderním „zánikem rigidní moderní éry“, $\mathrm{s}$ oslabováním disciplinárních procesů, $\mathrm{s}$ „odklonem od velkých názorových systémů“. V tomto procesu jedinci usilují o větši pružnost a soukromou volbu s cílem „být sám sebou a mít právo na sociální uznání“ [Lipovetsky 1998: 15].

Přitom jde také o apoteózu konzumerismu, jenž se rozšiřil do soukromé sféry, jeho vnější fasáda sděluje módní lhostejnost ve jménu tzv. cool kultury, ve skutečnosti však často může jít o spotřebu identitních vzorů a prvkủ životního stylu, ke které je jednotlivec veden pestrobarevnou nabídkou. Jinými slovy: Lipovetski nepopírá, že jedinec je veden nabídkou, to znamená, působí na něj vnější společenské okolnosti, je popřípadě směrován či manipulován reklamním přesvědčováním. 
Výrazným rysem personalizace je emoční přesun z veřejné do soukromé sféry, jejž autor nazývá narcisismem, kdy se centrem světa stává vlastní Já. Takováto individualizace neznamená nějakou asociální nezávislost, je utvářením atomizovaných sítí zájmových kolektivit a kroužkủ sdružujících lidi v podobné životní situaci. Personalizace je psychologizací sociálního, veřejného a politického života [Lipovetsky 1998: 19].

Proces personalizace je dvojznačný a rozporný: na jedné straně je podle Lipovetského pokračováním moderní emancipace, je osobním osvobozením, v němž hlavní cíl spočívá v právu na odlišnost, rovnost a svobodnou volbu namísto úsilí o ráa pravdy a disciplíny. Autentické Já je důležitější než vzájemnost; vztah $\mathrm{k}$ sobě nahradil vztah k bližním: vztah k sobě je kultem těla jako osoby mající svou dủstojnost, staví se na odiv: osoba chce být obdivována. Narcismus kultu těla je psychologický, ale není svobodný a spontánní, navozuje „novou normalizaci být sám sebou, uctívání těla je společensky vyžadováno, je způsobem společenského ovládání“ [Lipovetsky 1998: 79]. Jedinec usiluje o soukromou emancipaci, je však závislý na informaci, reklamě a na spotřebním trhu. Zrychlování oběhu věcí a informací (také díky infotechnologiím) posiluje sebeurčení lidí v soukromém životě, na druhé straně však podle Lipovetského společnost ztrácí dřívější samostatnost a je stále více předmětem „všeobecného byrokratického programováni““ [tamtéž: 129]. Informovaný člověk nese sám za sebe odpovědnost a tato odpovědnost je narcisistní, individuální Já je roztř́štěné, roste nezájem o veřejné věci [tamtéž: 133] a podle Lipovetského je nejnaléhavější potřebou svoboda individua: „,... dnes se více toleruje sociální nerovnost než zákazy týkající se soukromé sféry" [tamtéž: 138].

Personalizace v modelu Lipovetského je vlastně emancipací přesunutou do soukromí, je privatizací identity jedince. Jedinec je spíše spotřebitelem než občanem a jako spotřebitel má ve sfére svého soukromí cvičit pružnost orientace ve světě nejistot trhu, práce i politické participace. A navíc právě narcisistní lhostejnost zastřešuje flexibilizaci individua. Lipovetsky konstatuje skutečnost, že moderni kapitalismus potřebuje pružnou ekonomickou socializaci pro stále častější experimenty a inovace, lhostejnost a apatie jsou podmínkou pro neomezené experimentování, zrychlování inovací a vykořistování. Lhostejnost je spojena s minimální motivací, s nestálostí a s nejistotou, jež vedou k destabilizaci chování a mínění [Lipovetsky 1998: 54-55]. Avšak nestálost a povrchnost jsou také spjaty s hodnotovou prázdnotou a přechodností. Personalizace přináší nezájem o veřejné záležitosti, privatizace snižuje politickou účast [tamtéž: 138]. V této souvislosti je postmodernismus $s$ jeho kulturou pokračováním moderního úsilí demokratizace estetického vkusu s rozpuštěním kulturního elitášství, ale zároveň je postmodernismus, ,jen jiné jméno pro označení morálního a estetického úpadku dnešni doby" [tamtéž: 147].

V informatizované společnosti nadbytku nejde o masovou spotřebu ani o autoritár̆skou kontrolu, jde o kontrolu sváděním, jež apeluje na narcisismus egoistického jedince, jakoby zbaveného masových rámců. Individuum žije v bezčasí a pěstuje život $v$ př́ítomnosti, což vyvolává problém, pokud jde o budoucnost demokracií [tamtéž: 264]. Lipovetsky v doslovu z roku 1993 hovoří o druhé individualistické revoluci rozpadu velkých společenských projektů a zániku donucovacích norem $\mathrm{s}$ kultem svobodného sebeurčení v soukromé sfére a v každodennosti, kde dřive jeho rozvoji bránily normy 
a instituce. Dnes máme místo utopie odpovědnost a místo protestu obhospodařování, narcis se vyznačuje subjektivni prací na sobě, na dnuhé straně se prohlubuje proces sociálni marginalizace. Neoliberální politika i hédonistická narcistická kultura oslavující naše Já a okamžité uspokojování našich přání souběžně rozdvojují demokracii, vyvolávají stále více normalizace i stále více sociálního vyloučení. Individualistický hédonismus vede lidi $\mathrm{k}$ péči o sebe, na druhé straně podkopává smysl úsilí a práce, vede $\mathrm{k}$ odspolečenštění a kriminalizaci. Lipovetsky věří, že tzv. druhá individualistická revoluce je teprve na počátku. Lipovetsky věři i tomu, že čím výraznější je subjektivní právo žít svobodně, tím více se společensky prosazují otázky hodnot a odpovědnosti, zároveň ale konstatuje, že přitom jde o bezbolestnou morálku bez povinnosti a postihu prrizpủsobenou nadvládě ega [Lipovetsky 1998: 268]. Souvislosti manipulace, kontroly a mocenské závislosti individualizace se takto poněkud vytrácejí.

\section{NEDOBROVOLNÁ INDIVIDUALIZACE V RIZIKOVÉ SPOLEČNOSTI: U. BECK}

Teorie rizikové společnosti U. Becka načrtla obraz nové globalizující konstelace moderní civilizace, ve které se mění sociální struktura i zdroje jistot života lidí: v rozvinuté moderní společnosti je produkce bohatství systematickou produkcí rizik a nejistot. $V$ této společnosti nejde pouze o využití sil prírody, o emancipaci člověka $\mathrm{z}$ tlakủ nouze a sociálních omezení, ale také o vedlejší důsledky vědecko-technického a ekonomického rozvoje. Globálně jde v soudobém světě o paralelní existenci a prolínání mezi konflikty rozdělování bohatství a konflikty rozdělování rizik. Toto prolínání působí v podmínkách globální nerovnosti mezi menšinou tzv. rozvinutých a většinou tzv. rozvojových zemí. Soudobá rizika jsou sociálně produkována novým stupněm dynamiky kapitalismu, $v$ niž se ekonomika stala relativně nezávislou na sociálnich a lidských potřebách. Tato rizika je možno identifikovat pomocí specializovaného vědění a jejich definicc jsou sociálně vyjednávány. Rizikủm jsou lidé vystaveni v nové civilizační připsanosti osudu, a to vytváŕí nové sociální konflikty a politické důsledky. Diskuse o riziku jsou závislé na vědeckém poznání a technických aparaturách, pouhá měření však nemohou odpovědět na lidské problémy jak žít, do diskusí vstupují lidské hodnoty a sociální zájmy, klíčový význam mají informační média. Sociální nerovnosti soudobého světa jsou rámcem, ve kterém se bohatství soustředuje nahoře a rizika se soustředují dole [Beck 2004: 45].

Beck dále upozornil na centrální problém souvislosti sociálnich makroprocesủ globalizace a individualizace. Podle něho jde do jisté míry o rozpor mezi individualizačním procesem a globalizací v kontextu tzv. světové rizikové společnosti (Weltrisikogesellschaft): paradoxem dnešní individualizace je stále menší možnost vyhýbat se soukromě rizikủm životního prostředí, zdraví či trhu práce. V tomto paradoxu vyniká na jedné straně nadměrná produkce rizik ve sfére globalizovaného byznysu a na druhé stále menší možnost ochrany a prevence lokálních důsledkủ pro jednotlivce i celé populace. Beck říká, že takto dochází $\mathrm{k}$ tomu, že zdánlivě viditelné bohatství stále vítězí nad neviditelnými riziky a slepota $\mathrm{k}$ rizikům je spojena s logikou výroby bohatství a s existujícími mocenskými vztahy. Rizika rozdělují podobně jako tržní šance svět na ty, kteři jsou převážně postiženi, a ty, kteří z rizik těží. S riziky se obchoduje, definice 
rizik vedou $\mathrm{k}$ dalším inovacím, novým trhům a ziskům, průmyslový systém živí to, co jej bytostně ohrožuje [Beck 2004: 75].

Podobně jako Lipovetsky věnuje se i Beck individualiaci v kontextu západních společností. Moderní západní průmyslové společnosti $\mathrm{v}$ procesu individualizace podle Becka zachovaly sociální nerovnosti, jež vystupují ne již v kolektivní třídní a rodinné podobě, ale $\mathrm{v}$ podobě individualizované. Procesy globalizace komplikují možnosti sociální regulace a odporu ve vztahu k mocným silám kapitalistické dynamiky ze strany institucí národního státu i sociálních hnutí. Jednotlivci byli v procesu modernizace v nedávné minulosti díky státu blahobytu vymaněni $z$ vlivu tradičních př́buzenských vztahủ, rodin, tř́id a stavủ a stali se nedobrovolně závislými na trhu práce. Vstup na trh práce se stal emancipační šancí a zároveň rizikem.

Beck hodnotí proces individualizace $\mathrm{v}$ rizikové globální situaci jako nedobrovolnou situaci, formy individualizované existence jsou situačně donucovány $\mathrm{k}$ tomu, aby centrem vlastních životních perspektiv a zpủsobu života bylo jednotlivcovo Já [Beck 2004: 117]. Lokální i globální nestabilita pracovního trhu a nestálost zaměstnání, flexibilita pracovních vztahủ i smíšené formy zaměstnanosti a nezaměstnanosti zostřuji individualizované sociální nerovnosti. Sociální nerovnost je nyní beztřídní a souvisí především s endemickou a masovou nezaměstnaností globalizovaného a technologicky inovujícícího technokapitalismu [Beck 1996].

Základní reprodukční jednotkou sociálna je jedinec, muž či žena. Tito jednotlivci jakožto aktéři tržně zprostředkovaného světa jsou nuceni na pozadí „riskantních svobod" plánovat své životy. Tato současná individualizace není zdařilou emancipací, dochází spíše ke standardizaci a institucionalizaci životních situací individuí závislých na trhu práce, vzdělání, spotřebě, právních předpisech, zdravotních a psychologických konzultacích a dopravních systémech [Beck 2004: 119]. V souvislosti s nadměrnou nabídkou ukončeného vzdělání a nedostatkem pracovních míst se znehodnocují kvalifikační předpoklady úspěchu individua na trhu práce: doklady o vzdělání jsou nezbytné pro účast $\mathrm{v}$ soutěži o stále ubývající pracovní místa, ale nejsou zárukou zajištění materiální situace [tamtéž: 138]. Masová nezaměstnanost vystupuje v kontextu individualizace jako osobní osud jedince postiženého ve specifické fázi života chudobou a frustrací. Jedinec usiluje o soukromou emancipaci, ale $v$ individualizovaných životních situacích zbavených třídních souvislostí se kolektivní osud stal osudem osobním [tamtéž: 143].

S tím kontrastují trendy narůstajícího rizika stát se nezaměstnaným, nebot žádná kvalifikační a profesní skupina už neskýtá ochranu před nezaměstnaností. Riziko je neosobním statistickým faktem, nebo se stává vyprávěním o osobnim selháni jednotlivého člověka; tím je ovšem privatizován systémový problém a vnějši př́činy se proměňují ve vlastní zavinění [tamtéž: 149].

\section{VZESTUP A PÁD PRÁCE: Z. BAUMAN}

Také Z. Bauman zdůraznil paralelitu soudobé globalizace a individualizace a souvislost flexibilizace kapitálu s velkou globální mobilitou a flexibilizací trhu práce na jedné straně a kulturní nejistotou sociálního života jednotlivých lidí na straně druhé. 
Globalizace ovládaná kapitálem nevytvárí systémově tlaky $\mathrm{k}$ individualizaci ve smyslu dobrovolné a svobodné emancipace, ale prohlubuje sociální nerovnosti: osud individua je určen situovaností ve stratifikované možnosti globálně se přesouvat. Menšina mobilních nahrazuje dřívějši „vládnoucí třídu“. Ostatní lidé jsou podle Baumana víceméně závislí na lokálních prostorech, tedy prostorech míst (spaces of place), jež kontrastuji s prostory toků (spaces of flows) kapitálu, informace aj. [Castells 1998]. Podle Castellse i Baumana situaci individuí tedy ovlivňuje nová globální stratifikace moci, která je v podstatě výsledkem znatelného přesunu moci ve směru od práce ke kapitálu v důsledku technologické a institucionální restrukturace globalizovaného ekonomického systému kapitalismu.

Anglické slovo labour historicky získalo trojí význam: fyzické námahy k zajištění hmotných potřeb, sociální kolektivity mající podíl na výrobě, politické činnosti a organizovaných zájmů těch, kteři pracují za mzdu. Podle ekonomického historika Karla Polanyiho bylo východiskem velké transformace na cestě ke zrodu průmyslové společnosti oddělení pracujicích od zdroje obživy. Výroba a směna se staly součástí obecného zpủsobu života, v němž byly práce, půda a peníze redefinovány ve zboží. Také člověk byl ekonomicky redefinován jako homo faber, homo oeconomicus a lidská práce se stala - tak jako půda a peníze - obchodovatelnou, směnitelnou, a tím také odcizitelnou a zpředmětněnou komoditou. Takto tržně redefinovaný člověk byl okraden o ochranu kulturních institucí [Polányi 2001: 76]. Klasická politická ekonomie oslavila práci jako lidskou emancipaci $\mathrm{z}$ př́rodní determinace, která je založena na racionálním myšlení a jednání. Práce je zdrojem bohatství, jehož je nutno rozumně využivat $\mathrm{k}$ maximální efektivnosti. Adam Smith viděl produkci bohatství jako přirozenou vlastnost racionálního sebezájmu lidských jedincủ a přirozenou součást života společností, národů. Proto také soudil, že taková společnost, většina jejíchž členů je chudá, nemůže rozkvétat. Naproti tomu reformátor R. Owen soudil, že především tovární systém je centrem zbídačení většiny lidí, je triumfem nomádského kapitálu i nomádské práce za mzdu; $v$ továrně došlo ke zbídačení lidství a jednotliví lidé, vytržení ze svých tradic i komunit a zbavení svých dovedností, jsou zde degradováni do pozice subsistenční závislosti. Hlavní sociální problém je sociální ponížení člověka, který byl vytěsněn.

Podle Baumana byl základem industriálního systému vztah vzájemné závislosti kapitálu a práce: práce je závislou na mzdě, kapitál na trhu práce, na němž ji nakupuje. Sociální smlouva mezi vlastníky kapitálu a vlastníky pracovní síly byla normou celého systému pravidel, institucí a vyjednávání. Povaha této smlouvy byla politicky utvářena $\mathrm{v}$ historickém procesu $\mathrm{v}$ podobě mocenského vztahu mezi kapitálem a prací. Instituce podniku vyvolala svou protiváhu $\mathbf{v}$ podobě instituce dělnických odborů. Obchod i trh práce byly garantovány a formovány moderním národním státem.

Kapitalistická koncentrace moci vytvořila velké monopoly, koncentrace moci státu se projevila v expanzi jeho sociálních funkcí včetně vnitřní i vnější pacifikace konfliktů. Instituce podniků, států i odborů se byrokratizovaly, vytvořily obraz kolektivně „organizovaného kapitalismu“ [Kocka] jako dlouhodobě stabilizovaného řádu relativních jistot s příslibem regulace nejistot a rizik. Tento systém se od 60 . let 20 . století rozkládá, hovoří se o konci historického kompromisu kapitálu a práce, o demontáži „demokratického kapitalismu“. Systém přestal vyhovovat především kapitálu, který 
díky souběhu různých faktorů začal tento organizovaný systém industriálního řádu vnímat jako strnulý a blokující. Místo stability a dlouhodobosti pronikly do organizace práce a podniku i do vztahů trhu práce flexibilita a krátkodobost. Nadnárodní sítě výrob a toky financí se stávají relativně nezávislými na lokálních trzích práce. Politiku národních států $\mathrm{v}$ oblasti hospodářství ovlivňují zájmové strategie nadnárodních kapitálových sil a rizika eskalující soutěže na světových trzích se transformují do sociálních a environmentálních dopadů $\mathrm{v}$ rámci hranic jednotlivých národních států, tedy v kontrastu mezi nadnárodními a lokálními sociálními prostory (viz Castellsovo rozlišení mezi prostorem tokủ a prostorem míst).

$\mathrm{V}$ dủsledku těchto mocenských změn se mění také povaha práce a podle Baumana to ovlivňuje i charakter individualizačních procesů. Jestliže se pracovní činnost stala krátkodobou záležitostí, byla zbavena pevné a garantované budoucnosti, nastalo to, že dnešní nejistota je mocná individualizující síla a solidarita jednotlivců ztrácí význam dřívější racionální taktiky, práce je spíše epizodický stav zaměstnání, nikoli povolání, rozvolňuji se reciproční vztahy mezi kapitálem a prací [Bauman 2004: 34-35], nastupují ponižující formy sociace, pracující chudoby aj. [R. Sennett 1998].

Podle Baumana se kapitál emancipoval od vztahu s prací tím, že se osvobodil od omezení pohybu a své reprodukce. Rozhodující je zde nový stupeň prostorové mobility, který umožňuje nátlak na lokální síly politicky vázané na určité území. V sázce je ekonomický rozvoj a investice do něj je nutno přilákat politikami „globálního přizpůsobeni““. Globálně mobilní nevázaný kapitál se takto stává nedostatkovým a zdražuje, kdežto lokálně vázané pracovní síly zlevňují (rưst populace ve světě přitom umožnil armádu nezaměstnaných označit za přebytečné lidi). Kapitál se internacionalizoval, trh práce je omezen rámcem národních státủ a regionů; kapitál se pohybuje rychleji, kdežto pracovní síla je ve své mobilitě omezena a je nadále omezována imigračními zákony, nebo deformována do podob lidské degradace včetně černého pracovního trhu organizovaného kriminálními gangy, obchodem s lidskými otroky a nucené práce [ILO 2005]. Kapitál je podle Baumana schopen využivat taktiku úniku a nomádského stěhování po celé planetě - nevázanost byznysu je jeho vyjednávací výhodou.

\section{UTVAR̆ENI PROCESU INDIVIDUALIZACE V RAMCI GLOBALIZOVANÉHO KAPITALISMU}

Práce zajímá kapitál méně než spotřeba, globálně mobilní byznys se orientuje především na spotřebitele. Marketingové slogany o globální odpovědnosti korporací se dnes hemži ztotožněním občana a spotřebitele. Zisky a výnosy závisejí více na spotřebitelích a na možnostech reprodukovat poptávku po nabízených symbolech a idejích než na zaměstnávaných pracovních silách. Nejžádanější profesí jsou „symboličtí analytikové“, kteři produkují ideje a manipuluji symboly a hodnotami spotřební kultury [Reich 1995]. Reklamy globalizující spotřební kultury usilují o využití motivů Lipovetského konceptu individualizace jako privatizace ve smyslu narcistní personalizace. V kontextu reality trhů práce globálně soutěžící, pružné podniky neustále zeštíhlují osazenstvo a restrukturují, zaměstnávaji stále méně stálých pracovníkủ a vystačí si s ,periferní pracovní silou“ ad hoc na krátkodobé dočasné smlouvy s omezením práv 
a povinností [Harvey 1989]. Tzv. sítový podnik využíá externí zdroje (outsourcing) a na dílčí krátkodobé smlouvy objednává dodávky výrob a služeb mnoha menších globálně a prostorově roztroušených firem [Castells 1996].

Flexibilita a dočasnost spolu s nejistotou rozdělují a individualizují, podlamují společný zájem a vedou $\mathrm{k}$ pomíjivé asociaci, deregulovaná tekutá moderna ruší jistoty pevné moderny, ruší svazek práce a kapitálu [Bauman 2004: 35]. Globalizovaná bída je založena na omezení pohybu a společenském vyloučení ze spotřební kultury a participace. Bauman se dokonce domnívá, že globalizované informace o bídě slouži $\mathrm{k}$ upevnění loajality spotřebitelủ, nebot je lepši žít v nejistotě flexibility než v jistotě chudoby: „Pohled na chudé je nutí, aby snášeli flexibilizaci světa a prekérnost své situace," přičemž v rámci individualizace v politické ekonomii nejistoty jsou ,vyhlídky na autonomní sebeurčení mdlé a mizivée " [Bauman 2004: 140]. Paradoxně právě na sebeurčení a samostatnost jednotlivce apeluje neoliberální konzervatismus, realita politické ekonomie nejistoty však požaduje pasivní adaptaci na hru bez pravidel, v níž individualizace rizik a privatizace pưsobí na znejistění lidí, nejistota má nahradit řád a moc využívá chaos $\mathrm{k}$ nové nadvládě. Bauman chápe podstatu modelu diferenciace globalizace jako globální mocenskou hierarchii, v níž nahoře jsou noví globální baroni a dole jsou lidé připoutaní k zemi, přčcemž mocenská elita těch nahoře ovládá ty dole svou exteritoriálností, prekérností a mobilitou, jež nahradily prítomnost mocných v místě, kde žiji ovládaní [Bauman 1999: 27-29]. Lidé ve slabší a nevýhodné pozici mohou udržet přelétavé investory a manažery tím, že je „přesvědčí o své neschopnosti odporovat“ [Bauman 2004: 47].

Beckova riziková společnost otevřela podle Baumana novou kapitolu v chápání procesu individualizace. Je jí historický proces, kterému chybí cíl a účel a který se pohybuje v peripetiích modernizace. Dnes tak jako dřive není individualizace záležitostí svobodné volby, ale spíše osudem mužủ i žen. To, že nemají na koho svalovat vinu za svoje frustrace a potiže, neznamená, že by se mohli před nimi uchránit svými soukromými prostředky, takže se individualizace jeví jako emancipace na oko [Bauman 2004: 61].

Beck si všímá reflexivního momentu, jak je vnímán institucionálně utvářený osud jedincủ v individualizované společnosti. Stejně jako Lipovetsky ukazuje Beck na to, že lidé jsou vytrhováni ze společenských vazeb a privatizováni, přičemž převládá ahistorické vnímání, prézentismus - vše se má točit kolem přitomnosti vlastního já. Na jedince působí tlaky $\mathrm{k}$ samostatnému psaní svého životopisu, $\mathrm{k}$ tomu, aby se sám rozhodoval. Rozhodování ve složitém světě turbulencí a dravé konkurence je však podmíněno napřiklad přístupem ke správným informacím. Beck ukazuje, že individualizované biografie jsou ovlivněny mnoha sociálními subsystémy, jež tak vstupují do soukromí: „Individualizované situace se vymykají rozlišování mezi systémem a životním světem“ [Habermas]. Hranice subsystémů procházejí individuálními situacemi. Ty jsou biografickou stránkou toho, co je institucionálně odděleno ... jde tedy o individualizované institucionální situace, ve kterých se život má stát „biografickým řešením rozporů systému“ [Beck 2004: 218].

Beck rovněž zdůraznil spíše problematickou a lidsky i sociálně nepříznivou stránku odtradičnění, které definoval jako rozklad kolektivních sociálních vazeb jednotlivce. Vytvoření globální celosvětové sítě médií digitalizované „network society“ [Castells 1996] je podle Becka vytvořením určitého rámce vtahování individua do „světové spo- 
lečnosti““. Světová společnost se takto stává součástí biografie [Beck 2004: 219]. To však neznamená ani novou sociální integraci, ani angažovanou účast při ovlivňování světových událostí. Globální média, zejména propojené informace vysílané televizemi, fungují jako nástroj politické regulace [Beck 2004: 213].

Bauman dále promýšlí politické dimenze roviny sociálního jednání: pokud individualizovaní lidé přijmou fakt, že sami nemohou kontrolovat podmínky svých životủ, pak ztratí odvahu $\mathrm{k}$ sebeurčení a $\mathrm{k}$ samosprávě, a tím ztratí i občanskou vůli. Fatalismus bezmoci je konformitou rezignace [Bauman 2004: 69]. Jestliže se $v$ globalizaci moc oddělila od politiky, je k obnově občanství a demokracie nutno „posílit politickou sféru, tak aby se pod politickou kontrolu dostaly síly, které z ní unikají, tzn. dostat politické instituce na stejnou úroveň globálnosti, na níž proudí síly, které dnes skutečně něco znamenaji“". Zároveň je skutečnost, že globální síly nejsou pod kontrolou tím, co nejvíce brání tomu, aby se „efektivní politické instituce pozvedly na globální rovinu“ [Bauman 2004: 72-73].

Organizační, technologické, institucionální a politické transformace $\mathbf{v}$ soudobé globalizaci mají komplexní sociální a lidské důsledky. Jedním z nich je námi analyzovaný charakter procesu individualizace utvářený postupnou mocenskou nerovnováhou mezi zaměstnanci a zaměstnavateli, investory a aktéry závislými na trzích práce, sociálními nerovnostmi a rủstem nejistoty šancí jednotlivcủ $v$ životě regulovaném sociálními institucemi. Nejde již pouze o nějakou obecnou krizi lidské adaptability na zrychlování sociálních změn, ale zdá se, že vzniká dilema ve vztahu mezi žádoucím samostatným jednáním odpovědného jedince a nepříznivými podmínkami, které jedinec nemůže ovlivnit svobodnou volbou. Na situovanost jednotlivcủ $v$ „globalizované společnosti“ má rostoucí vliv oslabení kolektivních sociálních mechanismủ regulace rizik, další oslabování sociálních solidarit, dopady sociálního vylučování spojené s riziky nezaměstnanosti: to vše $\mathrm{v}$ kontextu mocenské nerovnováhy mezi sociálními prostory tokủ a prostory míst.

\section{Literatura}

BAUMAN, Z. 1995. „Searching for a Centre that Holds“. In: Featherstone, M. - Lash, S. - Robertson, R. (eds.). Global Modernities. London: Sage, s. 140-154.

- 2000. Globalizace. Düsledky pro človeka. Praha: Mladá fronta.

- 2004. Individualizovaná společnost. Praha.

BAUDRILLARD, J. 1988. Selected Writings. Stanford: Stanford U.P.

BECK, U. 1996. „Kapitalismus ohne Arbeit?“ Der Spiegel, ‘. 20.

- 1999. World Risk Society. Polity: Cambridge.

- 2000. What is Globalization? Polity: Cambridge.

- 2004. Riziková společnost. Na cestě $k$ jiné moderně. Praha: SLON.

BUCHSTEIN, H. 2000. „Kyberobð̌ané a teorie demokracie“. Filosofický časopis, roč. 48, ‘. 6.

CASTELLS, M. 1996. The Information Age: Economy, Society and Culture. Volume I: The Rise of the Network Society. Oxford: Blackwell.

- 2004. The power of Identity. Oxford: Blackwell.

DRUCKER, P. F. 1993. Postkapitalistická společnost. Praha: Management Press.

ELGIN, D. 1981. Voluntary Simplicity. Toward a Way of Life that is Outwardly Simple, Inwardly Rich. New York: William Morrow and Company, Inc. 
FERGUSSON, M. 1982. Aquarian Conspiracy. Personal and Social Transformation in the 80es. London, Toronto: Granada Publ.

GIDDENS, A. 1998. Düsledky modernity. Praha: SLON.

HABERMAS, J. 1981. Theorie der kommunikativen Handelns. Frankfurt a. M.: Bd. I, Suhrkamp.

HARVEY, D. 1989. The Condition of Postmodernisty. London: Routledge.

ILO 2003. Global Employment Trends. Ženeva.

LASH, S. 1999. Another Modernity. A Different Racionality. Oxford: Blackwell.

LEVY, P. 2000. Kybcrkultura. Praha.

LIPOVETSKY, G. 1998. Éra prázdnoty. Praha: Prostor.

LUKE, T. 1999. „Simulated Sovereigty, Telematic Territoriality: The Political Economy of Cyberspace“. In: Featherstone, M. - Lash, S. (eds.). Spaces of Culture. City-Nation-World. London: Sage.

- 1995. „The New World Order or Neo-World Orders: Power, Politics and Ideology in Informationalizing Glocalities“. In: Featherstone, M. - Lash, S. - Robertson, R. (eds.). Global Modernities. London: Sage, s. 91-107.

MARCUSE, H. 1991. Jednorozměrný člověk. Praha: Naše vojsko.

MASUDA, Y. 1980. The Information Society as a Post-industrial Society. Tokio: Institute for the Information Society.

MCLUHAN, M. 1991. Rozumět médiim. Praha: Odeon.

MILLER, M. 1994. „Where is Globalization Taking Us?“. Futures, č. 2, s. 123-143.

OFFE, C. 2000. „Společnost práce, budoucnost práce“. In: Pongs, A. V jaké společnosti vlastně žijeme? Praha: ISV, s. 183-204.

POLANYI, K. 2001. The Great Transformation. The Political and Economic Origins of Our Time. Boston. RAMONET, I. 1998. Die Neuen Herren der Welt. Zürich: Rotpunkt Verl.

REICH, R. 1995. Dilo národü. Př́iprava na kapitalismus 21. stoleti. Praha.

ROSENAU, J. 1990. Turbulence in World Politics. Princeton: Princeton U.P.

SASSEN, S. 1999. „Digital Networks and Power“. In: Featherstone, M. (ed.). Spaces of Culture. London: Sage, s. 49-63.

SENNETT, R. 1998. The Corrosion of Character. The Personal Consequences of Work in the New Capitalism. New York.

- 1999. „Growth and Failure: The New Political Economy and its Culture“. In: Featherstone, M. (ed.). Spaces of Culture. London: Sage, s. 14-26.

SMART, B. 1990. Modern Conditions. Postmodern Controversies. London: Routledge.

SMITH, A. 1996. Software for the Self Culture and Technology. London.

STRANGE, S. 1994. „Rethinking Structural Change in the International Political Economy“. In: Stubbs R. Underhill, J. (eds.). Political Economy and the Changing Global Order. New York: St. Martin's Press, s. $103-115$.

THEOBALD, R. 1985. The Rapids of Change. New York: W. Morrow.

TOFFLER, A. - TOFFLEROVÁ, H. 2001. Nová civilizace: třetí vina. Praha.

\section{On the Current Connections between Informatization, Globalisation and Individualization}

\section{Su m mary}

Social changes are accelerating, globalisation and changes in information technologies are creating both an environment of new social risks and a need to prevent them. This article analyses the connections between informatization, globalisation and individualization in the political context and analyses a number of ambiguous social and cultural consequences. Impermanence and insecurity, and a new individualised dependence are affecting people's lives, work and communication. In this situation of dilemma (a gap between real conditions and individual free will), the need for political solutions is increasing. 